\title{
The environmental sustainability of insects as food and feed. A review
}

\author{
Arnold van Huis $^{1}$ (D) Dennis G. A. B. Oonincx ${ }^{1}$
}

Accepted: 24 August 2017 / Published online: 15 September 2017

(C) The Author(s) 2017. This article is an open access publication

\begin{abstract}
With a growing world population, increasingly demanding consumers, and a limited amount of agricultural land, there is an urgent need to find alternatives to conventional meat products. Livestock production is, moreover, a leading cause of anthropogenic-induced climate change. To mediate this, more sustainable diets are needed, with reduced meat consumption or the use of alternative protein sources. Insects are promoted as human food and animal feed worldwide. In tropical countries, edible insects are harvested from nature, but overexploitation, habitat changes, and environmental contamination threaten this food resource. Therefore, sustainable harvesting practices need to be developed and implemented. We provide examples of (1) aquatic insects whose populations are threatened by pollution, (2) caterpillar species in Africa that are disappearing due to overexploitation and habitat change, (3) edible insects species that are considered pests in agro-ecosystems, and (4) edible insect species that can be conserved and enhanced in forest management systems. Insect farming can be conducted either on small-scale farms or in large-scale industrialized rearing facilities. We review the environmental sustainability of insect farming compared to livestock production. The major environmental advantages of insect farming compared to livestock production are as follows: (1) less land and water is required; (2) greenhouse gas emissions are lower; (3) insects have high feed conversion efficiencies; (4) insects can transform low-value organic by-products into highquality food or feed; and (5) certain insect species can be used as animal feed or aqua feed. For instance, they can replace fish meal, which is becoming increasingly scarce and expensive.
\end{abstract}

Arnold van Huis

arnold.vanhuis@wur.nl

1 Laboratory of Entomology, Wageningen University and Research, PO Box 16, 6700 AA Wageningen, Netherlands
However, edible insect species intended for production should be screened for risks to humans, animals, plants, and biodiversity.

Keywords Climate change $\cdot$ Edible insects $\cdot$ Environmental impact · Feed conversion efficiency · Insect farming .

Life cycle analysis $\cdot$ Overharvesting $\cdot$ Pollution

\section{Contents}

1. Introduction

2. Need to replace current protein sources

2.1 Climate change and dietary changes

2.2 Alternative protein sources

3. Sustainability of gathering edible insects from ecosystems

3.1 Aquatic insects threatened by pollution

3.2 Edible caterpillars threatened in Africa

3.3 Harvesting insects from agro-ecosystems

3.4 Conserving and enhancing the availability of wild populations

4. Environmental impact of insect production

4.1 Life cycle assessment

4.2 Feed Conversion efficiency

4.3 Reducing organic waste

4.4 Insects replacing fish meal as feed

5. Environmental risks of insect farming

6. Conclusions

Acknowledgements

References

\section{Introduction}

Insects are being proposed as an alternative protein source for humans, livestock, and fish (Van Huis et al. 2013). In tropical countries, there is a history of insect consumption by humans 
(Bergier 1941; Bodenheimer 1951; DeFoliart 2012). It is only recently that they have been considered as human food in the western world. Furthermore, there is an increased interest in using them as feed for pets, pigs, poultry, and fish. This growing academic interest is illustrated by the number of scientific publications on the topic. Using the term "edible insects" on the Web of Science (accessed 1 August 2017) yielded 53 publications for the year 2016, while in the 5-year periods 2006-2010 and 2011-2015, it was 25 and 83, respectively.

In tropical countries, edible insects are traditionally harvested from nature (Fig. 1). They contribute to food security, as they are often used for home consumption, or they provide a source of income when marketed. They are a seasonal product as most species depend on host plants. Increased deforestation, agricultural intensification (e.g., pesticide use), and environmental pollution may threaten the resource, while higher demand and increased prices could lead to overexploitation (Ramos-Elorduy 2006). The prices of edible insects, e.g., edible grasshoppers (Agea et al. 2008) and palm weevils (Ayemele et al. 2016), are often higher than those for meat products.

Apart from being collected from nature, insects can also be reared in confined industrial facilities (Oonincx and de Boer 2012). Western countries are now investigating the potential of this approach, prompted by the need to find alternative protein sources. These alternatives are needed because demand for meat products is increasing while the available land area for livestock production is limited (Van Huis 2015). In addition, current livestock production contributes greatly to a number of environmental problems such as acidification due to leaching of ammonia, climate change due to greenhouse gas emissions, deforestation, soil erosion, desertification, loss of plant biodiversity, and water pollution. These are highlighted in Steinfeld et al. (2006) and later in other publications (Gerber et al. 2013; Herrero et al. 2015; Herrero et al. 2016). The question is whether the production of insects as an alternative protein source is environmentally more sustainable than the production of conventional animals (Abbasi et al. 2015, Gahukar 2016).

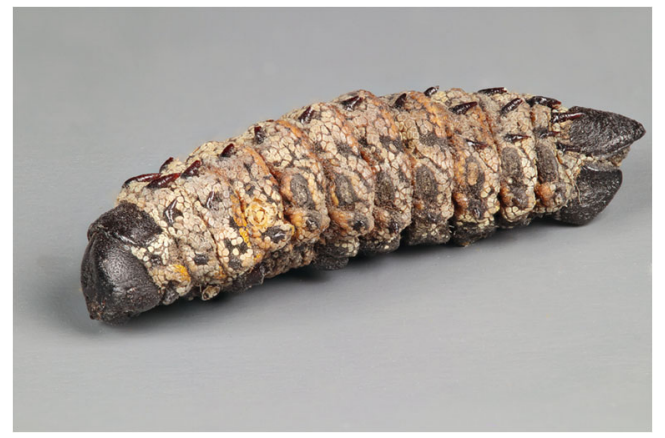

Fig. 1 Mopane caterpillar (Imbrasia belina) — sun dried. Photocredits and copyright: Hans Smid - www.bugsinthepicture.com
Sustainability in an agricultural setting can be defined as practices that meet current and future societal needs for food and fiber, for ecosystem services, and for healthy lives and that do so by maximizing the net benefit to society when all costs and benefits of the practices are considered (Tilman et al. 2002). Another definition goes even further, stating that sustainable systems should be "socially supportive" and "commercially competitive" (Gold 2016). This review focuses on environmental aspects of sustainability. For an extensive review of ecosystem services from edible insects, we refer to Payne and Van Itterbeeck (2017).

If insects are to be considered as feed (Fig. 2), the market will require huge and guaranteed quantities of a high and standard quality. The feed market increased by $14 \%$ between 2011 and 2015, totaling 464 million $\mathrm{t}$ for poultry, 254 million $\mathrm{t}$ for pigs, 35 million $t$ for cultured fish, and 23 million $t$ for pets (Alltech 2016). This means that there is an enormous potential market for insects as feed, But the question is whether insects would use fewer natural resources than livestock (Marone 2016).

In the following paragraphs, we discuss the urgent need to find alternative protein sources, the necessity to change our diets, the environmental issues related to harvesting from nature, the environmental impact of farming insects as mini-livestock compared to the conventional livestock species, and the risks associated with insect farming (Fig. 3).

\section{Need to replace current protein sources}

The demand for meat products is expected to increase from current levels by more than $75 \%$ in 2050 due to population growth and rising incomes. The per capita increase will be larger in developing countries (from $28 \mathrm{~kg}$ in 2005/2007 to $42 \mathrm{~kg}$ in 2050) than in developed countries (from 80 to $91 \mathrm{~kg}$ ) (Herrero et al. 2015). Moreover, the relative increase in volume is more pronounced in developing countries (113\%) than in developed countries (27\%) (Alexandratos and Bruinsma

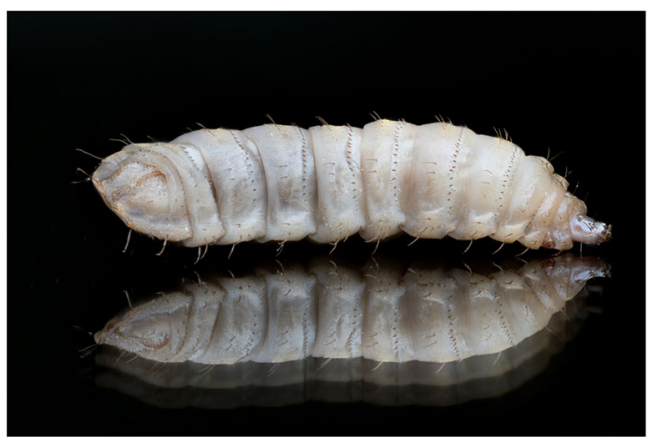

Fig. 2 Larva of the black soldier fly (Hermetia illuscens). Photocredits and copyright: Hans Smid - www.bugsinthepicture.com 


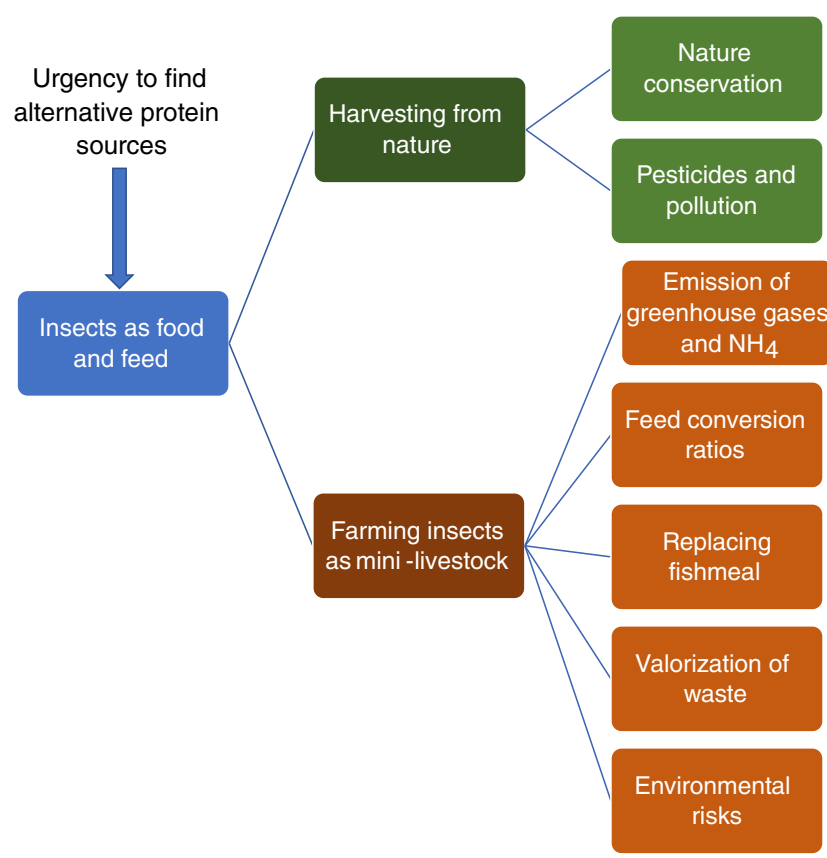

Fig. 3 Environmental issues involved when insects are harvested or when reared as production animals or mini-livestock

2012; p. 94). It is somewhat disproportional that meat represents $15 \%$ of the total energy in the global human diet, while approximately $80 \%$ of agricultural land (3,400 million ha as pastures and 500 million ha as crop land) is used for animal grazing or the production of livestock feed and fodder (Herrero et al. 2015; Herrero et al. 2016). Furthermore, livestock decreases food supply, since the grains fed to pigs and poultry could be used for human consumption. About a third of the world's cereal production is fed to animals (Mottet et al. 2017). The increase in global demand for meat and the restricted availability of land prompt the search for alternative protein sources.

\subsection{Climate change and dietary changes}

At the Paris climate conference in December 2015, 195 countries signed the first ever universal, legally binding global climate deal (Sutter and Berlinger 2015). The agreement sets out a global action plan to limit climate change to less than $2{ }^{\circ} \mathrm{C}$ above pre-industrial levels. The aim is to limit this increase to $1.5^{\circ} \mathrm{C}$, which would significantly reduce the impacts of climate change (Wollenberg et al. 2016).

Livestock is an important contributor to climate change. The 20 billion domesticated food-producing animals produce between 5.6 and $7.5 \mathrm{Gt} \mathrm{CO}_{2}$ equivalents per year, cattle being responsible for $64-78 \%$ of these emissions (Herrero et al. 2016). The main sources are methane $\left(\mathrm{CH}_{4}\right)$ from enteric fermentation and animal manure (43\%), $\mathrm{N}_{2} \mathrm{O}$ from manure and slurry management $(29 \%)$, and $\mathrm{CO}_{2}$ from land use changes and fossil fuel usage (27\%). These emissions reflect non- efficient use of initial inputs and resources in the form of loss of energy, nutrients, and soil organic matter (Gerber et al. 2013; Herrero et al. 2016). These authors indicate that half of the mitigation potential for agriculture, forestry and land use sectors lies within livestock production. Examples of such measures are reducing the demand for livestock products, reducing emissions from manure, and increasing carbon sequestration in rangelands.

The first point about reducing the demand for livestock products is, at least in theory, a powerful mitigation option (Schösler et al. 2012; Hedenus et al. 2014; Davis et al. 2016; Herrero et al. 2016; Lamb et al. 2016). This is particularly true for ruminant meat. The production of $1 \mathrm{~kg}$ of beef requires about 50 times more land than the production of $1 \mathrm{~kg}$ of vegetables, while greenhouse gas emissions are about 100 times higher, all depending on the production system used (Nijdam et al. 2012). A noteworthy exception are marginal lands which can be used for ruminants, but are unsuitable for crop production (Van Zanten et al. 2016). Western diets are characterized by a high intake of meat, dairy products, and eggs, as a consequence of which the consumption of saturated fat and red meat exceeds dietary recommendations (Westhoek et al. 2014). Halving the consumption of these products would reduce greenhouse gas emissions by $65 \%$ in the UK (Scarborough et al. 2014) and by $25-40 \%$ in the European Union (Westhoek et al. 2014). This can be achieved by substituting animal protein with vegetable protein and making a transition from ruminants (e.g., cattle and sheep) (McAlpine et al. 2009; Tilman and Clark 2014; Bryngelsson et al. 2016) to lower impact species (e.g., pigs and poultry) (Steinfeld and Gerber 2010). Reducing meat consumption and combining this with land sparing have the potential to reduce greenhouse gas emissions (Lamb et al. 2016) and increase biodiversity (Phalan et al. 2011). Another mitigation measure is using feed with a low environmental impact for the production of fish, pigs or poultry.

\subsection{Alternative protein sources}

One suggested alternative protein source is in vitro cultured meat (Post 2012). Although with large uncertainty ranges, life cycle analyses indicate that the overall environmental impacts of cultured meat production could be lower than those of most conventionally produced meat (Tuomisto and Teixeira de Mattos 2011; Mattick et al. 2015). However, a great deal of research is still needed to establish an industrial-scale culturing system (Fayaz Bhat and Fayaz 2011). Other alternative protein sources investigated both as food and feed are as follows: seaweed (Mohamed et al. 2012; Makkar et al. 2016), duckweed (Appenroth et al. 2017), canola/rapeseed (Campbell et al. 2016), micro-algae and other microbes (Vigani et al. 2015), and insects (Van Huis et al. 2013). The latter option is the primary focus of this review. 


\section{Sustainability of gathering edible insects from ecosystems}

Most of the approximately 2,100 insect species consumed by humans in the tropics (Jongema 2017) are harvested from nature (forests, waterways, or agricultural fields). Utilizing this food resource requires safeguarding their environment. For example, care should be taken when using pesticides to control forest caterpillars as they are sources of protein, minerals and vitamins for people in Central Africa. Insects contribute significantly to the food security and livelihoods of the poor, especially women and children, who sell insects on the market or use them for personal consumption (Kalaba et al. 2013; Lindsey et al. 2013; Vantomme et al. 2004).

When harvesting a popular, high-priced insect from nature, one of the dangers is overexploitation, which can endanger future harvests. In Australia, honey ants and wood grubs (both Lepidoptera and Coleoptera) were important edible insect species for the aboriginals (Yen 2005; Yen et al. 2016). However, increased exploitation by the indigeneous population, for restaurants and for ecotourism, threatens their availability (Yen 2009). Ramos-Elorduy (2006) recorded 18 species from the state of Hidalgo, Mexico, threatened by pollution, habitat change, and overexploitation. This is called "anthropocene defaunation" by Van Vliet et al. (2016); humans cause a local population decline or even species extirpation. We give examples of aquatic insects whose populations are threatened due to pollution: caterpillar species in Africa, which are disappearing due to overexploitation and logging; edible insect species considered pests in agro-ecosystems; and insect species that can be conserved and enhanced in natural ecosystems.

\subsection{Aquatic insects threatened by pollution}

The eggs of aquatic true bugs (Hemiptera) called "ahuauhtle" were regarded as a delicacy by the Aztecs, and even the Spanish conquistadores called them 'Mexican caviar' (Bachstez and Aragon 1945). The eggs, measuring 0.5 to $1.0 \mathrm{~mm}$, come from Krizousacorixa spp., Corisella spp., Corixa spp. (Hemiptera: Corixidae), and Notonecta spp. (Hemiptera: Notonectidae) and are collected from lakes in central Mexico (Guérin-Méneville 1858; Bergier 1941: p. 154-155). Great quantities of these eggs are deposited on the surfaces of aquatic vegetation throughout the year. Nowadays, the insects are lured to deposit their eggs on artificial lakebed nurseries (Parsons 2010). These are made by manually inserting clumps of grass into the shallow lake bottom using a wooden or iron stake in long U-shaped lines about $1 \mathrm{~m}$ apart. It was estimated that 3,900 MT of insect eggs could be harvested in pre-Columbian times on the original lake surface of 10,000 ha. Nowadays, the eggs go for a high price, especially during the week before Easter, the Christian holy week. However, dried up lake beds (Ramos-Elorduy 2006) and pollution due to inappropriate waste treatment (BadilloCamacho et al. 2015) are endangering this practice.

The Loktak lake is the largest freshwater lake in northeast India. Aquatic insects are vanishing from its natural habitat due to ongoing degradation of the lake's water quality (Samom 2016). The lake is host to 31 aquatic edible insect species. One of the most popular, the giant water bug Lethocerus indicus (Lepeletier \& Serville, 1825) (Hemiptera: Belostomatidae), is locally called 'Naosek'. In summer, it was abundantly available in paddy fields, the lake periphery, and on the local markets. Due to continued use of pesticides and fertilizers, the bug is slowly vanishing from its habitat. Aquatic insects that disappear from their habitat directly impact both Manipur's lake ecosystem and the food culture of the people living there, who have an age-old tradition of consuming these giant water bugs.

\subsection{Edible caterpillars threatened in Africa}

The Bisa people in the Kopa area of the Miombo woodlands (Brachystegia spp.) commercially harvest two Zambian edible caterpillar species (Gynanisa maja Strand and Imbrasia zambesina Walker (Lepidoptera: Saturniidae) (Mbata et al. 2002). Traditionally harvesting was regulated by (i) monitoring host plant abundance and changes in ecosystems; (ii) protecting vulnerable life stages; (iii) protecting specific habitats, e.g., late woodland fires destroy both host plants and moth eggs and larvae, so early burning is recommended (Leleup and Daems 1969; Holden 1991); and (iv) restricting harvesting to certain periods (Holden 1991). This was enforced by (i) roles assigned to the people that monitor, i.e., village headmen and other authorities; (ii) taboos and regulations on caterpillar harvesting, e.g., people are said to go insane when consuming young instars or be bitten by a snake or struck by lightning when picking too early (Holden 1991); and (iii) social and religious sanctions associated with caterpillar harvesting. The Bisa people, young and old, internalized these traditional management practices through various rituals, ceremonies and other cultural processes. However, traditional rules are disappearing because of westernization (Kenis et al. 2006) and people cut down trees to harvest caterpillars. Population pressure, poverty, and high demand for caterpillars from outside buyers cause these changes (Hobane 1995). Mbata et al. (2002) recommended that the government encourage the traditional resource use and management system of the Bisa people.

In the Central African Republic, companies selectively logged sapelli (Entandrophragma cylindricum Sprague), which is a host tree of the edible caterpillar Imbrasia oyemensis Rougeot (Lepidoptera: Saturniidae) (Vantomme et al. 2004). The loggers left one tree per 10 ha in order to allow natural regeneration. However, this is one tenth of the 
pre-cutting frequency, which significantly reduced both the caterpillar supply and the regeneration of the sapelli tree.

In some parts of Botswana and South Africa, caterpillars, in particular the mopane caterpillar, Imbrasia belina (Westwood) (Lepidoptera: Saturniidae) (Fig. 1) was affected due to overexploitation. Moreover, bush fires, debarking, and the collection of branches and trunks for firewood and construction purposes compromised the caterpillar population (Illgner and Nel 2000). Mopane caterpillars have one generation emerging between November and January and a second between March and May. Gondo et al. (2010) proposed three strategies for sustainably harvesting these caterpillars: leave sufficient fifth instar larvae to pupate and produce the next generation; do not harvest pupae; and conserve the mopane woodlands. Therefore, some communities restrict harvesting to certain time periods and impose a fee on harvesters. Communitybased natural resource management systems need to be institutionalized to make this successful (Akpalu et al. 2009).

\subsection{Harvesting insects from agro-ecosystems}

Agricultural intensification strategies focus on attaining higher yields. However, this should be done with a minimum impact on the environment. Therefore, Godfray and Garnett (2014) call for "sustainable intensification." For edible insects, this means also paying attention to the services they provide, besides their role as a source of nutrients. Payne and Van Itterbeeck (2017) reviewed such ecosystem services worldwide and classified a selected group of edible insect species according to provisioning, regulating, and maintaining and the cultural services they provide.

The most common way of controlling insects in agriculture, even the edible ones, is to use chemicals. However, if they are edible, why not control them by harvesting them for food and feed? The advantages are threefold: (1) nutritional, contributing to food security; (2) economic because no pesticides are purchased; and (3) environmental, as there is no pesticide contamination, and pest resurgence or secondary outbreaks are prevented. We provide examples of locusts and grasshoppers from Latin America, Africa, and Asia.

A suitable species is the Mexican grasshopper Sphenarium purpurascens Charpentier (Orthoptera: Pyrgomorphidae). This species is a pest of corn, bean, pumpkin, and alfalfa in central and southern Mexico. However, it has also been exploited for human consumption since prehistoric times. Currently, $200 \mathrm{t}$ is consumed per year (Cerritos and CanoSantana 2008). If this species were harvested from the more than 1 million ha of these agroecosystems in Mexico, the potential annual yield would be 350,000 t. Therefore, Cerritos et al. (2015) proposed changing the practice from chemical to mechanical control.

In sub-Saharan Africa, more than 60 grasshopper and locust species are eaten, most of which are crop pests (Van Huis
2003). These orthopterans are millet pests in the Sahelian region; however, their sale yields more revenue for farmers than the millet sales (Van Huis 2016). This is one of the reasons why farmers prefer not to treat their crops with pesticides.

The Bombay locust Nomadacris succincta (Johannson) (Orthoptera: Acrididae) was a major pest of corn and sorghum crops in Thailand between 1960 and 1970 (Chen et al. 1998). Aerial spraying did not successfully control the pest, and from 1978 to 1981, a campaign was held to revive an old practice from the past, i.e., capturing and eating the locust (Hanboonsong 2010). Farmers started to collect them for personal consumption and as a market commodity; hence, it is no longer considered a pest. On the contrary, $170 \mathrm{t}$ is imported annually from Cambodia (Ratanachan 2009, cited in Hanboonsong et al. 2013).

In most of Asia, rice field grasshoppers of the genus Oxya spp. (Orthoptera: Acrididae) are traditional food. In Korea, during the 1960s and 1970s, the government attempted to modernize the countryside, mandating the use of insecticide in rice fields. This greatly reduced grasshopper populations (Pemberton 1994). In the 1980s, the government changed and put less emphasis on the countryside. Farmers, especially in some highland areas, stopped using insecticides, and there was a revival of grasshoppers as food. Also in Japan, grasshoppers of the genus Oxya are one of the most consumed insects. In the past, their collection was widespread, but it has now declined. Both sellers and consumers attribute this to increased pesticide use in the final quarter of the twentieth century (Payne 2015).

During outbreaks and plagues, locusts are popular food in Kuwait. Locusts that invaded Kuwait during the winter of 1988-1989 were analyzed for pesticides. These contained chlorinated pesticides and relatively high concentrations of organophosphorus pesticides, which made consumption of these insects a health risk (Saeed et al. 1993).

\subsection{Conserving and enhancing the availability of wild insect populations}

How can the predictability and availability of wild populations be increased to avoid overexploitation? Van Itterbeeck and Van Huis (2012) mention providing egg-laying sites of reed and grasses for aquatic Hemiptera in the lakes of Mexico and manipulating host trees to facilitate the collection of palm weevil larvae and foliage-consuming caterpillars.

In Cameroon, the traditional harvesting of larvae of the African palm weevil Rhynchophorus phoenicis (Fabricius) (Coleoptera: Curculionidae) involved facilitation. This yielded 35 larvae per trunk, while a semi-farming system yielded 50 larvae (Ayemele et al. 2016). In the semi-farming system, fewer (20-35\%) trunks are cut. However, a single collector can cut down 1100 raffia trunks per season, and this is an unsustainable practice. Muafor et al. (2015) 
developed a system in which palm weevils were collected and put into boxes containing fresh raffia. This system uses $75 \%$ less raffia compared to the semi-farming system and can be implemented throughout the year.

Another example of conserving trees concerns the bamboo caterpillars, Omphisa fuscidentalis Hampson (Lepidoptera: Crambidae), which were traditionally collected by cutting down entire bamboo clumps. However, it is now proposed to cut a rectangular hole at the internodes hosting the bamboo caterpillars. This makes it unnecessary to cut down the whole plant. The infested bamboo culms are used for bamboo handicraft and construction poles, which are actually stronger than the non-infested ones (Hanboonsong et al. 2013).

The Asian weaver ant Oecophylla smaragdina Fabricius (Hymenoptera: Formicidae) is one of the most favored edible insects in Lao PDR and Thailand. It also functions as a biological control agent in tropical crops, including mango orchards. Providing the ants with a small amount of cat food and some sugar water doubled the yield and can be considered as ant farming with a dual purpose: biological control of pest insects and obtaining a food source (Offenberg and Wiwatwitaya 2009).

The conservation and enhancement of edible insects from the wild should also take into account the complex and dynamic relationships between ecosystems, collectors, consumers, traders, timber producers, and the different exogenous drivers of change (such as climate change) that either affect the social or the ecological components of the system (Van Vliet et al. 2016). The focus should not be solely on maximum yields based on ecological principles, but also on social interaction leading to adaptive resource management and governance. Conducive agroforestry practices are needed, and tenure and access should be part of it, with their corresponding institutional frameworks and regulations regarding conflict management between different stakeholders (Lindsey et al. 2013; Vantomme et al. 2004). Vinceti et al. (2013) consider the challenge of the next few decades in areas where gathering is firmly rooted in rural cultures: (1) maintaining wildlife species within a network of protected areas and (2) meeting the rural demand for proteins through sustainable harvesting.

Vantomme et al. (2004) call for more research into captive rearing of forest-based insect species and host plants. However, when insects are promoted for human consumption or for animal feed, the amounts necessary are so large that wild populations cannot satisfy the demand and then insects need to be farmed.

\section{Environmental impact of insect production}

In this section, the environmental impact of farming insects as mini-livestock will be compared with that of raising common production animals in terms of greenhouse gas emissions, energy, land and water use, and feed conversion efficiency. The ability of insects to convert low-value organic sidestreams into high-value protein products will be discussed and also whether they are able to replace fish meal as a protein ingredient in feed.

\subsection{Life cycle assessment}

When insects are produced, either as a source of food or feed, this has an impact on the environment. This impact can be divided into direct and indirect impact. For instance, due to the respiration and metabolism of these insects and their feces, $\mathrm{CO}_{2}, \mathrm{CH}_{4}, \mathrm{~N}_{2} \mathrm{O}$, and $\mathrm{NH}_{3}$ can be emitted. Direct emission levels were only quantified for five insect species. However, these levels seem to be lower than for conventional livestock (Oonincx et al. 2010). Additional studies on direct greenhouse gas emissions from edible insects are needed to provide a more complete picture (Halloran et al. 2016). These are interesting from a physiological perspective. However, indirect emissions, as well as other parameters of environmental impact, should also be considered. The method of choice for such assessments is the life cycle assessment (LCA), which has a supply chain approach that quantifies environmental impact of a product through the entire chain. To date, LCAs have only been published for mealworms, house crickets, black soldier flies, and houseflies (Oonincx and de Boer 2012; Miglietta et al. 2015; Roffeis et al. 2015; Van Zanten et al. 2015; Smetana et al. 2016, Halloran et al. 2017).

These LCAs enable comparisons of insect production systems with benchmarks. Mealworms, used as a protein rich food, can be compared to meat and milk. Houseflies and black soldier flies, as protein rich feed ingredients, can be compared to fish meal and soy bean meal. These studies indicate that the energy use of insect production systems is high compared to benchmarks. Energy requirements are high due to the need for relatively high temperatures during rearing. This is because insects are poikilothermic: their body temperatures depend mainly on ambient temperatures. On the other hand, it also means that the feed consumed by insects can be efficiently used for growth: energy in the feed does not need to be used for maintaining a constant body temperature.

The production of feed is a major driver of environmental impact in conventional livestock systems and insect production systems are no exception. This seems obvious for land use; as an example, the production facility for mealworms was associated with $0.2 \%$ of the total land use, whereas the feed used in this facility was associated with $99 \%$ of the land use (Oonincx and De Boer 2012). Similarly, the direct water use of that facility was only a fraction of the water (including rain water) needed for the production of feed (Miglietta et al. 2015). When compared to chicken, $1 \mathrm{~g}$ of edible protein requires two to three times as much land and 50\% more water compared 
to mealworms (Oonincx and De Boer 2012; Miglietta et al. 2015). A gram of edible protein from beef requires 8-14 times as much land and approximately 5 times as much water compared to mealworms. Also with respect to greenhouse gas emmissions, mealworms have a lower environmental impact than convention livestock systems. Broiler chickens are associated with 32-167\% higher emissions, and beef cattle emit 613 times more $\mathrm{CO}_{2}$ equivalents, when compared to mealworms on an edible protein basis (Oonincx and De Boer 2012).

Similarly, poultry production in Thailand is associated with $89 \%$ higher greenhouse gas emissions, on an edible protein basis, than crickets (Halloran et al. 2017). These authors report several more indicators of environmental impact (15 in total). On most reported aspects cricket production had a similar or lower impact than poultry production. Smetana et al. (2015) compared the environmental impact of several meat substitutes, based on a similarly large selection of indicators. They concluded that insect-based and soy meal-based products were associated with the lowest environmental impact. As was also concluded by Smetana et al. (2016), insect-based food can be an environmentally friendlier alternative to conventional high protein products.

These studies indicate that the energy use of insect production systems is high compared to benchmarks. As said, the high-energy requirements are due to the need for relatively high ambient temperatures for these poikilothermic insects, but this also means they have relatively low requirements for dietary energy. Within the livestock and insect production chain, the majority of land and water use, as well as the total greenhouse gas emissions, is associated with feed production. The efficient use of feed therefore explains the relatively low requirements in terms of land and water in insect production chains compared to their respective benchmarks.

Comparing the environmental impact of housefly larvae, used as feed, with their benchmarks is less straightforward. Whereas fish meal is associated with high energy use and concomittant high greenhouse gas emissions, associated land use is negligible. In contrast, soy bean meal production requires a lot of land but uses a limited amount of energy. Greenhouse gas emissions associated with soy bean meal are low if only direct emissions are taken into account. When associated deforestation (so-called land use changes) is taken into account, these emissions are higher than for fish meal. If housefly meal is directly compared to a 50:50 mixture of fish meal and soybean meal, the land use decreases by $98 \%$, global warming potential decreases by $61 \%$, and energy use decreases by $38 \%$ (Van Zanten et al. 2015). However, the feed that is used for fly production would not be available for other uses, such as anaerobic digestion. If this indirect effect is taken into account, the net energy requirement of housefly meal is approximately $40 \%$ higher and the global warming potential is approximately twice as high compared to the previously mentioned 50:50 mixture. However, land use is still greatly reduced $(97 \%)$. As stated before, the feed used in a production system greatly affects the environmental impact of such a system. These effects were quantified for black soldier fly larvae. What becomes apparent is that low-value by-products (e.g., chicken manure or DDGS) can result in a low environmental impact (Smetana et al. 2015). However, beet pulp, which can also be considered a low-value by-product, resulted in the highest environmental impact. This was because larvae developed poorly on beet pulp and therefore required a lot of feed and energy for heating.

When it comes to insects as feed, the context as well as the insects' feed utilized in the production process plays a key role. The design of energy-efficient facilities, combined with an efficient use of feed ingredients, is expected to lead to decreases in the environmental impact of insect production systems in the coming decades. More LCAs should be conducted to evaluate such novel facilities. Also, a wider range of production locations should be considered as this can greatly influence environmental impact, especially energy use. Furthermore, a wider range of impact categories could be considered for evaluating the strengths and weaknesses of insect production systems (Halloran et al. 2016).

\subsection{Feed conversion efficiency}

One of the main reasons why insects are considered as potentially sustainable sources of animal protein is because of their high feed conversion efficiency (Nakagaki and deFoliart 1991; Berenbaum 1995; Gullan and Cranston 2005; RamosElorduy 2008; Premalatha et al. 2011; Looy et al. 2013). The reason for this expectation is that insects are poikilothermic. This, however, does not necessarily lead to greater efficiency. High efficiency requires optimal diets and therefore knowledge of the nutritional requirements of insect species needs to be established. Furthermore, much like in conventional farming, genetic selection can further help to create efficient strains. There are, however, indications that several insect species accumulate protein very efficiently (Oonincx et al. $2015 b)$. Whereas poultry provided with optimized diets converts $33 \%$ of dietary protein to edible body mass, yellow mealworms utilize $22-45 \%$ of dietary protein, black soldier fly larvae about half (43-55\%), and Argentinean cockroaches 51 to $88 \%$. The latter species is able to do so by using endosymbionts. These data illustrate that the starting level of protein efficiency, without optimizing genetic background or diets, is already high compared to conventional livestock.

Whereas optimal diets would lead to more efficient use, this is not necessarily the most sustainable and economic way to produce insects. When seen from an environmental point of view, valorizing unused or underused substrates, such as certain organic side-streams, should be explored further 
(Oonincx et al. 2015b, Halloran et al. 2016, Halloran et al. 2017).

\subsection{Reducing organic waste}

A number of species can successfully be grown on organic side streams, converting low-value organic by-products into high-value proteins. This is particularly important considering that on a yearly basis, $27 \%$ of all our agricultural produce is wasted and $22 \%$ if only the edible part is taken into account, or globally 1.6 and 1.3 billion t, respectively (FAO 2013). Agricultural waste was valued at US\$750 billion annually (The Economist 2014). The by-product that can be used depends on the insect species. Mealworms can be raised on dried organic waste materials from fruit and vegetable origin (Ramos-Elorduy et al. 2002). Van Broekhoven et al. (2015) and Oonincx et al. (2015b) mixed dried by-products from beer brewing, bread/cookie production, potato processing, and dried distiller grains with solubles dried distillers grains with solubles (DDGS), a by-product of the biofuel industry. The mealworms developed well on several of these mixtures and had a fairly constant nutrient composition.

Part of the same diets were also given to house crickets (Acheta domesticus (L.) (Oonincx et al. 2015b). These, however, did not do well on most of these mixtures. Similarly, Lundy and Parrella (2015) found that the nutrient requirements of this species has narrow ranges and concluded that its potential as a source of sustainable protein depends on the availability of relatively high-quality by-products, preferably not currently used in livestock production.

The oriental ground cricket, Teleogryllus testaceus (Walker), farmed as food in Cambodia, seems to have a broader diet and can be grown on unused resources such as leaves from taro and cashew and cassava tops (Megido et al. 2016). Miech et al. (2016) found that this species performs well on cassava plant tops, but also on several weeds, in particular Cleome rutidosperma.

The best-known species for utilizing waste streams, such as rice straw (Manurung et al. 2016), coffee pulp (Larde 1990), fish offal (St-Hilaire et al. 2007), DDGS (Webster et al. 2015), catering waste (Surendra et al. 2016) and swine, chicken and cattle manure (Sheppard et al. 1994; Newton et al. 2005; Oonincx et al. 2015a) is the black soldier fly (Fig. 2). It utilizes this waste and can simultaneously kill pathogenic bacteria such as Escherichia coli or Salmonella enterica present in, for instance, chicken or cattle manure (Erickson et al. 2004; Liu et al. 2008). It has even been proposed as a sanitation method for getting rid of human feces (Lalander et al. 2013; Banks et al. 2014). Furthermore, the black soldier fly can be used to produce biodiesel and biofuel (Zheng et al. 2012; Li et al. 2015; Surendra et al. 2016). The housefly can also be grown on manure (Cicková et al. 2012; Shah et al. 2016). The suitability of Diptera for transforming organic waste into high protein feed products was outlined by Pastor et al. (2015). However, they indicated that other fly species such as Muscidae (houseflies), Stratiomyidae (soldier flies), Calliphoridae (blowflies), Sarcophagidae (flesh flies), and Syrphidae (hover flies) should also be considered. The choice of substrates used depends on legislative frameworks; e.g., in the European Union, the use of organic by-products such as catering waste and manure is prohibited. Furthermore, food and feed safety issues need to be taken into account, especially when organic by-products are used; for a review see EFSA (2015).

\subsection{Insects replacing fish meal as feed}

Whereas aquaculture provided only $7 \%$ of fish for human consumption in 1974, this share had increased to $44 \%$ by 2014 (FAO 2016b). In 2014, about $10 \%$ of total fish produced (captured and aquaculture) was reduced to fish meal and fish oil. Fish meal is made from small wild-caught marine fish that contain a high percentage of bones and oil, and are usually deemed unsuitable for direct human consumption. Fish meal is a high-quality feed ingredient for pigs, poultry, and aquaculture and is used extensively. However, it is becoming increasingly scarce and expensive. This is partially the result of overexploitation of wild fish stocks (more than $30 \%$ of fish stocks in 2013) (FAO 2016b). Therefore, between 1988 and 2010, the poultry sector decreased the use of fish meal from 60 to $12 \%$ of the total available amount. However, the aquaculture sector increased its use of fish meal from 10 to $56 \%$ in the same period. Although increasing fish meal prices have led to lower inclusion percentages in aquafeed, this effect is offset by the rapid growth of the aquaculture sector (Olsen and Hasan 2012; Msangi et al. 2013). This fuels the search for alternative sources, for instance the use of plant material. Plant sources have a number of drawbacks such as a lower protein content and the presence of anti-nutritional factors, which reduce nutrient availability and counteract with vitamins (Olsen and Hasan 2012). These drawbacks can partly be mediated by chemical and mechanical processing (Hall 2015).

However, certain insect species might also serve as alternative protein sources without these drawbacks, in particular the black soldier fly Hermetia illucens (L.) (Diptera: Stratiomyidae). Tests conducted with Atlantic salmon showed that complete replacement of fish meal had no adverse effects on net growth of the fish, histology, odor, flavor/taste, and texture (Lock et al. 2015). Similarly, meal made from the black soldier fly is a suitable protein source for a number of other farmed fish species, such as African catfish Clarias gariepinus (Adeniyi and Folorunsho 2015; Anvo et al. 2016), channel catfish Ictalurus punctatus, and blue tilapia Oreochromis aureus (Bondari and Sheppard 1987).

Another insect species, the yellow mealworm (Tenebrio molitor L.; Coleoptera: Tenebrionidae), has also been 
evaluated. Yellow mealworm meal could partially (35\%) replace fish meal in the diet of European sea bass (Dicentrarchus labrax) without affecting mortality or growth (Gasco et al. 2016). However, replacing 70\% of the fish meal did depress growth. A similar trial conducted with rainbow trout (Oncorhynchus mykiss) found that weight gain was not affected at higher inclusion levels of mealworm meal, while the protein content increased and lipid contents of fillets decreased, compared to the control (Belforti et al. 2015). A complete replacement of fish meal by yellow mealworm meal increased the fat content of Pacific white shrimp, but did not affect its growth or feed conversion (Panini et al. 2017). In contrast, common catfish (Ameiurus melas Raf.) fingerlings and African catfish, C. gariepinus, grew slower when large proportions of the fish meal were replaced $(\mathrm{Ng}$ et al. 2001; Roncarati et al. 2015).

It seems that partial replacement is possible but, depending on the fish species, might affect production characteristics. Furthermore, replacing fish meal by yellow mealworm or black soldier fly meal decreases the concentration of longchained omega-3 fatty acids, which may then need to be added to the fish diet (Makkar et al. 2014).

\section{Environmental risks of insect farming}

Questions are often asked about the potential environmental risks of replacing the current livestock systems with insect farming systems. Is there a danger for humans, plants, animals, and biodiversity? The legislative framework in a country should be checked, e.g., does a country have a list of animals that are allowed to be produced?

Then it depends on whether an organism can be considered a quarantine pest, which is "a pest of potential economic importance to the area endangered thereby and not yet present there, or present but not widely distributed and being officially controlled", as defined under the International Plant Protection Convention (IPPC), an international agreement that aims to protect cultivated and wild plants by preventing the introduction and spread of pests. Worldwide there are nine Regional Plant Protection Organizations (RPPOs) of the IPPC (FAO 2016a). The task of these organizations is to protect the world's cultivated and natural plant resources from the spread and introduction of plant pests. This is done by regulating the imports of insect species and vehicles thereof. If the insect species is not endemic, would be able to survive in nature if it escaped, and would pose a danger to humans, animals, plants, or biodiversity, the use of this species can, and maybe should, be prohibited.

A proper identification of the insect species is necessary as is information about their origin. Risks assessments are made by the National Plant Protection Services and the National
Food Safety Authorities which are part of Ministries of Agriculture.

Besides the species that fall into the Q organism category, other species produced for food or feed can be a nuisance. For example, a farm producing house flies should not let these escape, as they can bother the general public. Hence, precautions should be made to keep insects inside; for instance, all openings to the rearing should be sealed or filtered.

\section{Conclusions}

In tropical countries, increased insect consumption leads to higher prices and, consequently, increased collection from nature, which may jeopardize the long-term sustainability of this practice. In order to assure future harvests, it is necessary to develop sustainable harvesting practices. Other threats to this natural resource are habitat changes, pesticide use, or pollution.

Furthermore, the increased use of insects as food and feed is expected to require more volume than can be harvested from nature. Therefore, farming the insects as mini-livestock is advisable. The high environmental impacts connected with meat production and the increase in demand up till 2050 require dietary changes. Insect-based meat substitutes are potentially more sustainable but require more advanced cultivation and processing techniques (Smetana et al. 2015). Such advancement is expected as the whole sector of insects as food and feed is just emerging.

In comparison to current production practices, this potential abundant food source can contribute to a more sustainable food and feed production, as certain insects can be reared on organic side streams, including manure. However, food and feed safety issues need to be considered.

Insect production has great potential with respect to sustainably providing food for the growing population. However, further technological development of this sector and monitoring of the effects of these developments on the environmental impact of insect production are needed.

Acknowledgements The authors would like to thank Hans Smid (www.bugsinthepicture.com) for allowing us to use the photos of two insect species (Figs. 1 and 2). Photographs were optimized for increased depth of field by making multiple images taken at various distances with a camera (Canon M5) mounted on a Stackshot automated macro rail (Cognisys, Traverse city, MI, USA). Resulting stacks of images were processed in Zerene stacker software v. 1.04 (Zerene systems, Richland, WA, USA).

Open Access This article is distributed under the terms of the Creative Commons Attribution 4.0 International License (http:// creativecommons.org/licenses/by/4.0/), which permits unrestricted use, distribution, and reproduction in any medium, provided you give appropriate credit to the original author(s) and the source, provide a link to the Creative Commons license, and indicate if changes were made. 


\section{References}

Abbasi T, Abbasi T, Abbasi SA (2015) Reducing the global environmental impact of livestock production: the minilivestock option. J Clean Prod 112:1754-1766. https://doi.org/10.1016/j.jclepro.2015.02.094

Adeniyi OV, Folorunsho CY (2015) Performance of Clarias gariepinus (Burchell, 1822) fed dietary levels of black soldier fly, Hermetia illucens (Linnaeus, 1758) prepupae meal as a protein supplement. Int J Res Fish Aquat 5:89-93

Agea JG, Biryomumaisho D, Buyinza M, Nabanoga GN (2008) Commercialization of Ruspolia nitidula (Nsenene grasshoppers) in Central Uganda. Afr J Food Agric Dev 8:319-332. https://doi.org/ 10.4314/ajfand.v8i3.19195

Akpalu W, Muchapondwa E, Zikhali P (2009) Can the restrictive harvest period policy conserve mopane worms in southern Africa? A bioeconomic modelling approach. Environ Dev Econ 14:587-600. https://oi.org/10.1017/S1355770X0900518X

Alexandratos N, Bruinsma J (2012) World agriculture towards 2030/2050: the 2012 revision. Global Perspective Studies Team ESA Working paper No. 12-03 Agricultural Development Economics Division Food and Agriculture Organization of the United Nations. doi:www.fao.org/economic/esa

Alltech (2016) 2016 global feed survey https://cdn2.hubspot.net/hubfs/ 745395/PDFs/2016GFS-Booklet_SE3.pdf. Accessed 1 Aug 2017

Anvo MPM, Toguyéni A, Otchoumou AK, Zoungrana-Kaboré CY, Kouamelan EP (2016) Evaluation of Cirina butyrospermi caterpillar's meal as an alternative protein source in Clarias gariepinus (Burchell, 1822) larvae feeding. Int J Fish Aquat Stud 4(6):88-94

Appenroth K-J, Sree KS, Böhm V, Hammann S, Vetter W, Leiterer M, Jahreis G (2017) Nutritional value of duckweeds (Lemnaceae) as human food. Food Chem 217:266-273. https://doi.org/10.1016/j. foodchem.2016.08.116

Ayemele AG, Muafor FJ, Levang P (2016) Indigenous management of palm weevil grubs (Rhynchophorus phoenicis) for rural livelihoods in Cameroon. J Insects Food Feed 3:43-50. https://doi.org/10.3920/ JIFF2016.0002

Bachstez M, Aragon A (1945) Notes on Mexican drugs, plants, and foods. III. Ahuauhtli, the Mexican caviar. J Am Pharm Assoc 34: 170-172. https://doi.org/10.1002/jps.3030340605

Badillo-Camacho J, Reynaga-Delgado E, Barcelo-Quintal I, del Valle PFZ, López-Chuken UJ, Orozco-Guareño E, AlvarezBobadilla JI, Gomez-Salazar S (2015) Water quality assessment of a tropical Mexican lake using multivariate statistical techniques. J Environ Prot 6:215-224. https://doi.org/10.4236/jep.2015.63022

Banks IJ, Gibson WT, Cameron MM (2014) Growth rates of black soldier fly larvae fed on fresh human faeces and their implication for improving sanitation. Tropical Med Int Health 19:14-22. https://doi. org $/ 10.1111 /$ tmi. 12228

Belforti M, Gai F, Lussiana C, Renna M, Malfatto V, Rotolo L, Marco MD, Dabbou S, Schiavone A, Zoccarato I, Gasco L (2015) Tenebrio molitor meal in rainbow trout (Oncorhynchus mykiss) diets: effects on animal performance, nutrient digestibility and chemical composition of fillets. Ital J Anim Sci 14:4170. https://doi.org/10.4081/ijas. 2015.4170

Berenbaum MR (1995) Bugs in the system. Helix books, AddisonWesley Publishing Company, Reading

Bergier E (1941) Peuples entomophages et insectes comestibles: étude sur les moeurs de l'homme et de l'insecte. Imprimerie Rullière Frères, Avignon

Bodenheimer FS (1951) Insects as human food; a chapter of the ecology of man. Dr. W. Junk, Publishers, The Hague

Bondari K, Sheppard DC (1987) Soldier fly, Hermetia illucens L., larvae as feed for channel catfish, Ictalurus punctatus (Rafinesque), and blue tilapia, Oreochromis aureus (Steindachner). Aquac Fish Manag 18:209-220. https://doi.org/10.1111/j.1365-2109.1987.tb00141.x
Bryngelsson D, Wirsenius S, Hedenus F, Sonesson U (2016) How can the EU climate targets be met? A combined analysis of technological and demand-side changes in food and agriculture. Food Policy 59: 152-164. https://doi.org/10.1016/j.foodpol.2015.12.012

Campbell L, Rempel CB, Wanasundara JPD (2016) Canola/rapeseed protein: future opportunities and directions. Workshop proceedings of IRC 2015. Plants 2016, 5, 17. doi:https://doi.org/10.3390/ plants5020017

Cerritos R, Cano-Santana Z (2008) Harvesting grasshoppers Sphenarium purpurascens in Mexico for human consumption: a comparison with insecticidal control for managing pest outbreaks. Crop Prot 27:473-480. https://doi.org/10.1016/j.cropro.2007.08.001

Cerritos FR, Ponce-Reyes R, Rojas-García F (2015) Exploiting a pest insect species Sphenarium purpurascens for human consumption: ecological, social, and economic repercussions. J Insects Food Feed 1:75-84. https://doi.org/10.3920/JIFF2014.0013

Chen PP, Wongsiri S, Jamyanya T, Rinderer TE, Vongsamanode S, Matsuka M, Sylvester HA, Oldroyd BP (1998) Honey bees and other edible insects used as human food in Thailand. Am Entomol 44:24-29. https://doi.org/10.1093/ae/44.1.24

Cicková H, Pastor B, Kozánek M, Martínez-Sánchez A, Rojo S, Taká P (2012) Biodegradation of pig manure by the housefly, Musca domestica: a viable ecological strategy for pig manure management. PLoS One 7(3):e32798. https://doi.org/10.1371/journal.pone. 0032798

Davis KF, Gephart JA, Emery KA, Leach AM, Galloway JN, D'Odorico P (2016) Meeting future food demand with current agricultural resources. Glob Environ Chang 39:125-132. https://doi.org/10.1016/ j.gloenvcha.2016.05.004

DeFoliart G (2012) The human use of insects as a food resource: a bibliographic account in progress http://www.food-insects.com/

Economist (2014) Food loss and its intersection with food security. Global food security index 2014 Special report of the intelligence unit of The Economist http://foodsecurityindex.eiu.com/Home/ DownloadResource?fileName=EIU_GFSI\%202014_Special\% 20report_Food\%20loss.pdf. Accessed 1 Aug 2017

EFSA (2015) Risk profile related to production and consumption of insects as food and feed. EFSA J 13(10):4257. https://doi.org/10. 2903/j.efsa.2015.4257

Erickson MC, Islam M, Sheppard C, Liao J, Doyle MP (2004) Reduction of Escherichia coli O157:H7 and Salmonella enterica serovar Enteritidis in chicken manure by larvae of the black soldier fly. J Food Prot 67:685-690

FAO (2013) Food wastage footprint: impact on natural resources. Summary report. Food and Agriculture Organization of the United Nationa, Rome. http://www.fao.org/docrep/018/i3347e/i3347e.pdf

FAO (2016a) Regional plant protection organizations https:/www.ippc. int/en/external-cooperation/regional-plant-protectionorganizations/. Accessed 1 Aug 2017

FAO (2016b) The state of world fisheries and aquaculture: opportunities and challenges. Food and Agriculture Organization of the United Nations (FAO), Rome

Fayaz Bhat Z, Fayaz H (2011) Prospectus of cultured meat - advancing meat alternatives. J Food Sci Technol 48:125-140. https://doi.org/ 10.1007/s13197-010-0198-7

Gahukar RT (2016) Chapter 4 - edible insects farming: efficiency and impact on family livelihood, food security, and environment compared with livestock and crops. In: Dossey AT, Morales-Ramos JA, Rojas MG (eds) Insects as sustainable food ingredients. Academic Press, San Diego, pp 85-111. https://doi.org/10.1016/B978-0-12802856-8.00004-1

Gasco L, Henry M, Piccolo G, Marono S, Gai F, Renna M, Lussiana C, Antonopoulou E, Mola P, Chatzifotis S (2016) Tenebrio molitor meal in diets for European sea bass (Dicentrarchus labrax L.) juveniles: growth performance, whole body composition and in vivo 
apparent digestibility. Anim Feed Sci Technol. https://oi.org/10. 1016/j.anifeedsci.2016.07.003

Gerber PJ, Steinfeld H, Henderson B, Mottet A, Opio C, Dijkman J, Falcucci A, Tempio G (2013) Tackling climate change through livestock - a global assessment of emissions and mitigation opportunities. Food and Agriculture Organization of the United Nations (FAO), Rome

Godfray HCJ, Garnett T (2014) Food security and sustainable intensification. Phil Trans R Soc B 369(1639). https://doi.org/10.1098/rstb. 2012.0273

Gold MV (2016) Sustainable agriculture: the basics. Chapter 1. Sustainable agriculture: definitions and terms. Sustainable agriculture and food supply. In: Etingoff K (ed) Scientific, Economic, and Policy enhancements. Apple Academic Press, Waretown, pp 3-16. https://doi.org/10.1201/b19837-3

Gondo T, Frost P, Kozanayi W, Stack J, Mushongahand M (2010) Linking knowledge and practice: assessing options for sustainable use of mopane worms (Imbasia belina) in southern Zimbabwe. J Sustain Dev Afr 12:281-305

Guérin-Méneville M (1858) On 'Hautlé', or animal bread, of the Mexicans. Ann Mag Nat Hist 2:313-315 http://www. biodiversitylibrary.org/page/2265239\#page/332/mode/1 up. Accessed 1 Aug 2017

Gullan PJ, Cranston PS (2005) Insects as food: an outline of entomology. In: The insects. Blackwell Publishing, Oxford, pp 10-20

Hall GM (2015) Impact of climate change on aquaculture: the need for alternative feed. Turk J Fish Aquat Sci 15:569-574. https://doi.org/ 10.4194/1303-2712-v15 245

Halloran A, Roos N, Eilenberg J, Cerutti A, Bruun S (2016) Life cycle assessment of edible insects for food protein: a review. Agron Sustain Dev 36(4):57. https://doi.org/10.1007/s13593-016-0392-8

Halloran A, Hanboonsong Y, Roos N, Bruun S (2017) Life cycle assessment of cricket farming in north-eastern Thailand. J Clean Prod 156: 83-94. https://doi.org/10.1016/j.jclepro.2017.04.017

Hanboonsong Y (2010) Edible insects and associated food habits in Thailand. Forest insects as food: humans bite back. FAO regional Office for Asia and the Pacific, Bangkok

Hanboonsong Y, Jamjanya TT, Durst PPB (2013) Six-legged livestock: edible insect farming, collection and marketing in Thailand. Regional Office for Asia and the Pacific of the Food and Agriculture Organization of the United Nations, Bangkok

Hedenus F, Wirsenius S, Johansson DA (2014) The importance of reduced meat and dairy consumption for meeting stringent climate change targets. Clim Chang 124:79. https://doi.org/10.1007/ s10584-014-1104-5

Herrero M, Wirsenius S, Henderson B, Rigolot C, Thornton P, Havlík P, Id B, Gerber PJ (2015) Livestock and the environment: what have we learned in the past decade? Annu Rev Environ Resour 40:177202. https://doi.org/10.1146/annurev-environ-031113-093503

Herrero M, Henderson B, Havlik P, Thornton PK, Conant RT, Smith P, Wirsenius S, Hristov AN, Gerber P, Gill M, Butterbach-Bahl K, Valin H, Garnett T, Stehfest E (2016) Greenhouse gas mitigation potentials in the livestock sector. Nat Clim Chang 6(5):452-461. https://doi.org/10.1038/nclimate2925

Hobane PA (1995) AMACIMBI: the gathering, processing, consumption and trade of edible caterpillars in Bulilimamangwe District. Zimbabwe CASS Working Paper Series - NRM; 1/1995. Centre for Applied Social Sciences, University of Zimbabwe, Harare

Holden S (1991) Edible caterpillars - a potential agroforestry resource? They are appreciated by local people, neglected by scientists. Food Insects Newsl 4:3-4

Illgner P, Nel E (2000) The geography of edible insects in sub-Saharan Africa: a study of the mopane caterpillar. Geogr J 166:336-351 http://www.jstor.org/stable/823035

Jongema Y (2017) List of edible insect species of the world. Laboratory of Entomology, Wageningen University, Wageningen,
The Netherlands. http://www.entwurnl/UK/edible+insects/ worldwide+species+list/

Kalaba FK, Quinn CH, Dougill AJ (2013) Contribution of forest provisioning ecosystem services to rural livelihoods in the Miombo woodlands of Zambia. Popul Environ 35:159-182. https://doi.org/ 10.1007/s11111-013-0189-5

Kenis M, Sileshi G, Mbata K, Chidumayo E, Meke G, Muatinte B (2006) Towards conservation and sustainable utilization of edible caterpillars of the miombo. Trees for Poverty Alleviation ZIL Annual Conference, 9 June 2006, Zürich

Lalander C, Diener S, Magri ME, Zurbrügg C, Lindström A, Vinnerås B (2013) Faecal sludge management with the larvae of the black soldier fly (Hermetia illucens) - from a hygiene aspect. Sci Total Environ 458-460:312-318. https://doi.org/10.1016/j.scitotenv. 2013.04.033

Lamb A, Green R, Bateman I, Broadmeadow M, Bruce T, Burney J, Carey P, Chadwick D, Crane E, Field R, Goulding K, Griffiths H, Hastings A, Kasoar T, Kindred D, Phalan B, Pickett J, Smith P, Wall E, zu EKHJ E, Balmford A (2016) The potential for land sparing to offset greenhouse gas emissions from agriculture. Nat Clim Chang 6:488-492. https://doi.org/10.1038/nclimate2910

Larde G (1990) Recycling of coffee pulp by Hermetia illucens (Diptera, Stratiomyidae) larvae. Biol Wastes 33:307-310. https://doi.org/10. 1016/0269-7483(90)90134-E

Leleup N, Daems H (1969) Les chenilles alimentaires du Kwango. Causes de leur rarefaction et mesures preconisees pour y remedier. J Agric Trop Bot Appl 16:1-21

Li W, Li Q, Zheng L, Wang Y, Zhang J, Yu Z, Zhang Y (2015) Potential biodiesel and biogas production from corncob by anaerobic fermentation and black soldier fly. Bioresour Technol 194:276-282. https:// doi.org/10.1016/j.biortech.2015.06.112

Lindsey PA, Balme G, Becker M, Begg C, Bento C, Bocchino C, Dickman A, Diggle RW, Eves H, Henschel P, Lewis D, Marnewick K, Mattheus J, Weldon MJ, McRobb R, Midlane N, Milanzi J, Morley R, Murphree M, Opyene V, Phadima J, Purchase G, Rentsch D, Toche C, Shaw J, Van der Westhuizen H, Van Vliet N, Zisadza-Gandiwa P (2013) The bushmeat trade in African savannas: impacts, drivers, and possible solutions. Biol Conserv 160:80-96. https://doi.org/10.1016/j.biocon.2012.12.020

Liu Q, Tomberlin JK, Brady JA, Sanford MR, Yu Z (2008) Black soldier fly (Diptera: Stratiomyidae) larvae reduce Escherichia coli in dairy manure. Environ Entomol 37:1525-1530

Lock ER, Arsiwalla T, Waagbø R (2015) Insect larvae meal as an alternative source of nutrients in the diet of Atlantic salmon (Salmo Salar) postmolt. Aquac Nutr 22:1202-1213. https://doi.org/10. 1111/anu.12343

Looy H, Dunkel FV, Wood JR (2013) How then shall we eat? Insecteating attitudes and sustainable foodways. Agric Hum Values 31: 131-141. https://doi.org/10.1007/s10460-013-9450-x

Lundy ME, Parrella MP (2015) Crickets are not a free lunch: protein capture from scalable organic side-streams via high-density populations of Acheta domesticus. PLoS One 10(4):e0118785. https://doi. org/10.1371/journal.pone.0118785

Makkar HPS, Tran G, Heuzé V, Ankers P (2014) State-of-the-art on use of insects as animal feed. Anim Feed Sci Techn. https://doi.org/10. 1016/j.anifeedsci.2014.07.008

Makkar HPS, Tran G, Heuzé V, Giger-Reverdin S, Lessire M, Lebas F, Ankers P (2016) Seaweeds for livestock diets: a review. Anim Feed Sci Technol 212:1-17. https://doi.org/10.1016/j.anifeedsci.2015.09. 018

Manurung R, Supriatna A, Esyanthi RR, Putra RE (2016) Bioconversion of rice straw waste by black soldier fly larvae (Hermetia illucens $\mathrm{L}$.): optimal feed rate for biomass production. J Entomol Zool Stud 4: 1036-1041

Marone PA (2016) Chapter 7-food safety and regulatory concerns. In: Dossey AT, Morales-Ramos JA, Rojas MG (eds) Insects as 
sustainable food ingredients. Academic Press, San Diego, pp 203 221. https://doi.org/10.1016/B978-0-12-802856-8.00007-7

Mattick CS, Landis AE, Allenby BR, Genovese NJ (2015) Anticipatory life cycle analysis of in vitro biomass cultivation for cultured meat production in the United States. Environ Sci Technol 49:1194111949. https://doi.org/10.1021/acs.est.5b01614

Mbata KJ, Chidumayo EN, Lwatula CM (2002) Traditional regulation of edible caterpillar exploitation in the Kopa area of Mpika district in northern Zambia. J Insect Conserv 6:115-130. https://doi.org/10. 1023/A:1020953030648

McAlpine CA, Etter A, Fearnside PM, Seabrook L, Laurance WF (2009) Increasing world consumption of beef as a driver of regional and global change: a call for policy action based on evidence from Queensland (Australia), Colombia and Brazil. Glob Environ Chang 19:21-33. https://doi.org/10.1016/j.gloenvcha.2008.10.008

Megido RC, Alabi T, Nieus C, Blecker C, Danthine S, Bogaert J, Haubruge É, Francis F (2016) Optimisation of a cheap and residential small-scale production of edible crickets with local by-products as an alternative protein-rich human food source in Ratanakiri Province, Cambodia. J Sci Food Agric 96:627-632. https://doi. org/10.1002/jsfa. 7133

Miech P, Berggren Å, Lindberg JE, Chhay T, Khieu B, Jansson A (2016) Growth and survival of reared Cambodian field crickets (Teleogryllus testaceus) fed weeds, agricultural and food industry by-products. J Insects Food Feed 2:285-292. https://doi.org/10. 3920/JIFF2016.0028

Miglietta PP, De Leo F, Ruberti M, Massari S (2015) Mealworms for food: a water footprint perspective. Water 7:6190-6203. https:// doi.org/10.3390/w7116190

Mohamed S, Hashim SN, Rahman HA (2012) Seaweeds: a sustainable functional food for complementary and alternative therapy. Trends Food Sci Technol 23:83-96. https://doi.org/10.1016/j.tifs.2011.09. 001

Mottet A, De Haan C, Falcucci A, Tempio G, Opio C, Gerber P (2017) Livestock: on our plates or eating at our table? A new analysis of the feed/food debate. Glob Food Sec. https://doi.org/10.1016/j.gfs. 2017.01.001

Msangi S, Kobayashi M, Batka M, Vannuccini S, Dey MM, Anderson JL (2013) Fish to 2030: prospects for fisheries and aquaculture. World Bank rReport nNo 83177-GLB. World Bank, Washington, DC

Muafor FJ, Ayemele AG, Le Gall P, Levang P (2015) Exploitation, trade and farming of palm weevil grubs in Cameroon. Center for International Forestry Research (CIFOR), working paper 178, Bogor. 10.17528/cifor/005626

Nakagaki BJ, deFoliart GR (1991) Comparison of diets for mass-rearing Acheta domesticus (Orthoptera: Gryllidae) as a novelty food, and comparison of food conversion efficiency with values reported for livestock. J Econ Entomol 84:891-896. https://doi.org/10.1093/jee/ 84.3.891

Newton GL, Sheppard DC, Watson DW, Burtle GJ, Dove CR, Tomberlin JK, Thelen EE (2005) The black soldier fly, Hermetia illucens, as a manure management/resource recovery tool. State of the Science, Animal Manure and Waste Management Jan 5-7, San Antonio

Ng WK, Liew FL, Ang LP, Won KW (2001) Potential of mealworm (Tenebrio molitor) as an alternative protein source in practical diets for African catfish, Clarias gariepinus. Aquac Res 32:273-280. https://doi.org/10.1046/j.1355-557x.2001.00024.x

Nijdam D, Rood T, Westhoek H (2012) The price of protein: review of land use and carbon footprints from life cycle assessments of animal food products and their substitutes. Food Policy 37:760-770. https:// doi.org/10.1016/j.foodpol.2012.08.002

Offenberg J, Wiwatwitaya D (2009) Sustainable weaver ant (Oecophylla smaragdina) farming: harvest yields and effects on worker ant density. Asian Myrmecol 3:55-62
Olsen RL, Hasan MR (2012) A limited supply of fishmeal: impact on future increases in global aquaculture production. Trends Food Sci Technol 27:120-128. https://doi.org/10.1016/j.tifs.2012.06.003

Oonincx DGAB, De Boer IJM (2012) Environmental impact of the production of mealworms as a protein source for humans - a life cycle assessment. PLoS One 7(12):e51145. https://doi.org/10.1371/ journal.pone. 0051145

Oonincx DGAB, Van Itterbeeck J, Heetkamp MJW, Van den Brand H, Van Loon JJA, Van Huis A (2010) An exploration on greenhouse gas and ammonia production by insect species suitable for animal or human consumption. PLoS One 5(12):e14445. https://doi.org/10. 1371/journal.pone. 0014445

Oonincx DGAB, Van Broekhoven S, Van Huis A, Van Loon JJA (2015a) Feed conversion, survival and development, and composition of four insect species on diets composed of food by-products. PLoS One 10(12):e0144601. https://doi.org/10.1371/journal.pone. 0144601

Oonincx DGAB, Van Huis A, Van Loon JJA (2015b) Nutrient utilisation by black soldier flies fed with chicken, pig, or cow manure. J Insects Food Feed 1:131-139. https://doi.org/10.3920/JIFF2014.0023

Panini RL, Freitas LEL, Guimarães AM, Rios C, da Silva MFO, Vieira FN, Fracalossi DM, Samuels RI, Prudêncio ES, Silva CP, Amboni RDMC (2017) Potential use of mealworms as an alternative protein source for Pacific white shrimp: digestibility and performance. Aquaculture 473:115-120. https://doi.org/10.1016/j.aquaculture. 2017.02 .008

Parsons J (2010) The pastoral niche in pre-Hispanic Mesoamerica. In: Staller JE, Carrasco MD (eds) Pre-Columbian foodways: interdisciplinary approaches to food, culture, and markets in ancient Mesoamerica. Springer, New York, pp 109-136

Pastor B, Velasquez Y, Gobbi P, Rojo S (2015) Conversion of organic wastes into fly larval biomass: bottlenecks and challenges. J Insects Food Feed 1:179-193. https://doi.org/10.3920/JIFF2014.0024

Payne CLR (2015) Wild harvesting declines as pesticides and imports rise: the collection and consumption of insects in contemporary rural Japan. J Insects Food Feed 1:57-65. https://doi.org/10.3920/ JIFF2014.0004

Payne CLR, Van Itterbeeck J (2017) Ecosystem services from edible insects in agricultural systems: a review. Insects 8(1):24. https:// doi.org/10.3390/insects8010024

Pemberton RW (1994) The revival of rice-field grasshoppers as human food in South Korea. Pan Pac Entomol 70:323-327

Phalan B, Onial M, Balmford A, Green RE (2011) Reconciling food production and biodiversity conservation: land sharing and land sparing compared. Science 333(6047):1289-1291. https://doi.org/ $10.1126 /$ science. 1208742

Post MJ (2012) Cultured meat from stem cells: challenges and prospects. Meat Sci 92:297-301. https://doi.org/10.1016/j.meatsci.2012.04. 008

Premalatha M, Abbasi T, Abbasi T, Abbasi SA (2011) Energy-efficient food production to reduce global warming and ecodegradation: the use of edible insects. Renew Sust Energ Rev 15:4357-4360. https:// doi.org/10.1016/j.rser.2011.07.115

Ramos-Elorduy J (2006) Threatened edible insects in Hidalgo, Mexico and some measures to preserve them. J Ethnobiol Ethnomed 2:51. https://doi.org/10.1186/1746-4269-2-51

Ramos-Elorduy J (2008) Energy supplied by edible insects from Mexico and their nutritional and ecological importance. Ecol Food Nutr 47: 280-297. https://doi.org/10.1080/03670240701805074

Ramos-Elorduy J, Gonzalez EA, Hernandez AR, Pino JM (2002) Use of Tenebrio molitor (Coleoptera:Tenebrionidae) to recycle organic wastes and as feed for broiler chickens. J Econ Entomol 95:214-220

Roffeis M, Muys B, Almeida J, Mathijs E, Achten WMJ, Pastor B, Velásquez Y, Martinez-Sanchez AI, Rojo S (2015) Pig manure treatment with housefly (Musca domestica) rearing - an environmental 
life cycle assessment. J Insects Food Feed 1:195-214. https://oi. org/10.3920/JIFF2014.0021

Roncarati A, Gasco L, Parisi G, Terova G (2015) Growth performance of common catfish (Ameiurus Melas Raf.) fingerlings fed mealworm (Tenebrio molitor) diet. J Insects Food Feed 1:233-240. https://doi. org/10.3920/JIFF2014.0006

Saeed T, Dagga FA, Saraf M (1993) Analysis of residual pesticides present in edible locusts captured in Kuwait. Arab Gulf J Sci Res 11:1-5

Samom S (2016) Edible aquatic insects vanishing from Loktak. The Assam Tribune, May 19, Imphal

Scarborough P, Appleby PN, Mizdrak A, Briggs ADM, Travis RC, Bradbury KE, Key TJ (2014) Dietary greenhouse gas emissions of meat-eaters, fish-eaters, vegetarians and vegans in the UK. Clim Chang 125:179-192. https://doi.org/10.1007/s10584-014-1169-1

Schösler H, De Boer J, Boersema JJ (2012) Can we cut out the meat of the dish? Constructing consumer-oriented pathways towards meat substitution. Appetite 58:39-47. https://doi.org/10.1016/j.appet.2011. 09.009

Shah RM, Azhar F, Shad SA, Walker WB, Azeem M, Binyameen M (2016) Effects of different animal manures on attraction and reproductive behaviors of common house fly, Musca domestica L. Parasitol Res 115:3585-3598. https://doi.org/10.1007/s00436-0165124-0

Sheppard CD, Larry Newton G, Thompson SA, Savage S (1994) A value added manure management system using the black soldier fly. Bioresour Technol 50:275-279. https://doi.org/10.1016/09608524(94)90102-3

Smetana S, Mathys A, Knoch A, Heinz V (2015) Meat alternatives: life cycle assessment of most known meat substitutes. Int J Life Cycle Assess 20:1254-1267. https://doi.org/10.1007/s11367-015-0931-6

Smetana S, Palanisamy M, Mathys A, Heinz V (2016) Sustainability of insect use for feed and food: life cycle assessment perspective. J Clean Prod 137:741-751. https://doi.org/10.1016/j.jclepro.2016. 07.148

Steinfeld H, Gerber P (2010) Livestock production and the global environment: consume less or produce better? Proc Natl Acad Sci U S A 107:18237-18238. https://doi.org/10.1073/pnas.1012541107

Steinfeld H, Gerber P, Wassenaar T, Castel V, Rosales M, de Haan C (2006) Livestock's long shadow. Environmental issues and options. Food and Agriculture Organization of the United Nations (FAO, Rome

St-Hilaire S, Cranfill K, Mcguire MA, Mosley EE, Tomberlin JK, Newton L, Sealey W, Sheppard C, Irving S (2007) Fish offal recycling by the black soldier fly produces a foodstuff high in omega-3 fatty acids. J World Aquacult Soc 38:309-313. https:/ doi.org/10.1111/j.1749-7345.2007.00101.xView

Surendra KC, Olivier R, Tomberlin JK, Jha R, Khanal SK (2016) Bioconversion of organic wastes into biodiesel and animal feed via insect farming. Renewable Energy 98:197-202. https://doi.org/ 10.1016/j.renene.2016.03.022

Sutter JD, Berlinger J (2015) Final draft of climate deal formally accepted in Paris. CNN Cable News Network, Turner Broadcasting System, Inc. http://www.kpax.com/story/30731747/final-draft-of-climatedeal-formally-accepted-in-paris. Accessed 1 Aug 2015

Tilman D, Clark M (2014) Global diets link environmental sustainability and human health. Nature 515:518-522. https://doi.org/10.1038/ nature 13959

Tilman D, Cassman KG, Matson PA, Naylor R, Polasky S (2002) Agricultural sustainability and intensive production practices. Nature 418:671-677. https://doi.org/10.1038/nature01014

Tuomisto HL, Teixeira de Mattos MJ (2011) Environmental impacts of cultured meat production. Environ Sci Technol 45:6117-6123. https://doi.org/10.1021/es200130u

Van Broekhoven S, Oonincx DGAB, Van Huis A, Van Loon JJA (2015) Growth performance and feed conversion efficiency of three edible mealworm species (Coleoptera: Tenebrionidae) on diets composed of organic by-products. J Insect Physiol 73:1-10. https://doi.org/10. 1016/j.jinsphys.2014.12.005

Van Huis A (2003) Insects as food in sub-Saharan Africa. Insect Sci Appl 23:163-185

Van Huis A (2015) Edible insects contributing to food security? Agric Food Sec 4:20. https://doi.org/10.1186/s40066-0150041-5

Van Huis A (2016) Préface. In: Motte-Florac E, Le Gall P (eds) Savoureux insectes: de l'aliment traditionel à l'innovation gastronomique. Presses universitaires de Rennes/Institut de Recherche pour le développement, Tours, pp 7-10

Van Huis A, Van Itterbeeck J, Klunder H, Mertens E, Halloran A, Muir G, Vantomme P (2013) Edible insects: future prospects for food and feed security. FAO Forestry Paper 171. Rome, Food and Agriculture Organization of the United Nations (FAO), Rome and Wageningen University and Research Centre, Wageningen

Van Itterbeeck J, Van Huis A (2012) Environmental manipulation for edible insect procurement: a historical perspective. J. Ethnobiol Ethnomed 8:3. https://doi.org/10.1186/1746-4269-8-3

Van Vliet N, Daniel D, Beck H, Lindsey P, Nasi R, LeBel S, Moreno J, Fragoso J, Jori F (2016) Meat from the wild: extractive uses of wildlife and alternatives for sustainability. In: Mateo R, Arroyo B, Garcia JT (eds) Current trends in wildlife research. Springer, Cham, pp 225-265. https://doi. org/10.1007/978-3-319-27912-1_10

Van Zanten HHE, Mollenhorst H, Oonincx DGAB, Bikker P, Meerburg BG, De Boer IJM (2015) From environmental nuisance to environmental opportunity: housefly larvae convert waste to livestock feed. J Clean Prod 102:362-369. https://doi.org/10.1016/j.jclepro.2015. 04.106

Van Zanten HHE, Mollenhorst H, Klootwijk CW, Van Middelaar CE, De Boer IJM (2016) Global food supply: land use efficiency of livestock systems. Int J Life Cycle Assess 21:747-758. https://doi.org/ 10.1007/s11367-015-0944-1

Vantomme P, Göhler D, N'Deckere-Ziangba F (2004) Contribution of forest insects to food security and forest conservation: the example of caterpillars in Central Africa. Odi Wildlife Policy Briefing 3. https://www.odi.org/sites/odi.org.uk/files/odiassets/ publications-opinion-files/3306.pdf

Vigani M, Parisi C, Rodríguez-Cerezo E, Barbosa MJ, Sijtsma L, Ploeg M, Enzing C (2015) Food and feed products from micro-algae: market opportunities and challenges for the EU. Trends Food Sci Technol 42:81-92. https://doi.org/10. 1016/j.tifs.2014.12.004

Vinceti B., Ickowitz A, Powell B, Kehlenbeck K, Termote C, Cogill B, Hunter D (2013) The Contribution of forests to sustainable diets. Background paper for the International Conference on Forests for Food Security and Nutrition, 13-15 May 2013. FAO, Rome http:// www.fao.org/forestry/37132-051da8e87e54f379de4d7411aa3a3c32a. pdf

Webster CD, Rawles SD, Koch JF, Thompson KR, Kobayashi Y, Gannam AL, Twibell RG, Hyde NM (2015) Bio-Ag reutilization of distiller's dried grains with solubles (DDGS) as a substrate for black soldier fly larvae, Hermetia illucens, along with poultry byproduct meal and soybean meal, as total replacement of fish meal in diets for Nile tilapia, Oreochromis niloticus. Aquac Nutr 22:976988. https://doi.org/10.1111/anu.12316

Westhoek H, Lesschen JP, Rood T, Wagner S, De Marco A, MurphyBokern D, Leip A, Van Grinsven H, Sutton MA, Oenema O (2014) Food choices, health and environment: effects of cutting Europe's meat and dairy intake. Glob Environ Chang 26:196-205. https://doi. org/10.1016/j.gloenvcha.2014.02.004

Wollenberg E, Richards M, Smith P, Havlík P, Obersteiner M, Tubiello FN, Herold M, Gerber P, Carter S, Reisinger A, Van Vuuren D, Dickie A, Neufeldt H, Sander BO, Wassmann R, Sommer R, Amonette JE, Falcucci A, Herrero M, Opio C, Roman-Cuesta R, 
Stehfest E, Westhoek H, Ortiz-Monasterio I, Sapkota T, Rufino MC, Thornton PK, Verchot L, West PC, Soussana JF, Baedeker T, Sadler M, Vermeulen S, Campbell BM (2016) Reducing emissions from agriculture to meet the $2^{\circ} \mathrm{C}$ target. Glob Chang Biol 22:3859-3864. https://doi.org/10.1111/gcb.13340

Yen AL (2005) Insects and other invertebrate foods of the Australian aborigines. In: Paoletti MG (ed) Ecological implications of minilivestock: potential of insects, rodents, frogs and snails. Science Publishers, Inc., Enfield, pp 367-388

Yen AL (2009) Entomophagy and insect conservation: some thoughts for digestion. J Insect Conserv 13:667-670. https://doi.org/10.1007/ s10841-008-9208-8
Yen A, Bilney C, Shackleton M, Lawler S (2016) Current issues involved with the identification and nutritional value of wood grubs consumed by Australian aborigines. Insect Sci. https://doi.org/10. 1111/1744-7917.12430

Zheng L, Qing L, Jibin Z, Ziniu Y (2012) Double the biodiesel yield: rearing black soldier fly larvae, Hermetia illucens, on solid residual fraction of restaurant waste after grease extraction for biodiesel production. Renew Energy 41:75-79. https://doi.org/10.1016/j.renene. 2011.10.004 